\title{
ACCIDENT, MISTAKE, AND RULES OF LIABILITY IN THE FOURTEENTH-GENTURY LAW OF TORTS
}

\author{
Morris S. ARNold $†$
}

In the fourteenth century, it was evidently a familiar principle in the law of torts that no one was liable to make compensation for injuries attributable to some entirely providential cause. Tenants were therefore not liable in Waste for damage caused by tempests, ${ }^{1}$ earthquakes, ${ }^{2}$ or fires of spontaneous origin. ${ }^{3}$ The identical principle obtained in trespass: ${ }^{4}$ Fires that arose "suddenly" or "unbeknownst" to a defendant could not furnish a basis for fixing him with liability, even if they originated in his house. ${ }^{5}$ For example,

$f$ Professor of Law and History, and Director of the Office of the President, University of Pennsylvania. B.S.E.E. 1965, LL.B. 1968, University of Arkansas; LL.M. 1969, S.J.D. 1971, Harvard University.

I would like to acknowledge here my very real debt to the rather large number of people to whom most of the ideas in this Article were exposed for their comments and suggestions. Professor John H. Langbein was kind enough to invite me to present much of the present Article to his Workshop in Legal History at the University of Chicago Law School in March of 1979, and an earlier version of the present work was given to the Legal Studies Seminar at the University of Pennsylvania Law School in May of this year. I profited greatly from suggestions at both these places. I would, however, like to acknowledge especially the help provided by my colleagues Stephen B. Burbank, Alexander M. Capron, and Clarence Morris.

Some of the matters discussed in this Article are dealt with briefly in the introduction to my forthcoming book Select Cases of Trespass in the King's Courts, 1307-1399, to be published by the Selden Society. The treatment given them here, however, is both deeper and broader than seemed appropriate to an introduction to a collection of legal records. Moreover, the exposition here is a good deal more lawyer-like than one would expect to encounter in that context.

1 Walker, The Action of Waste in the Early Common Law, in LEGAL RECORDS AND THE HISTORTAN 185 (J. Baker ed. 1978).

2 CP 40/466, m. 59 (1377).

3 Walker, supra note 1 , at 198.

4 As used in the fourteenth century, the term "trespass" was synonymous with the modern term "tort." Thus, trespass actions included more than just actions against those who physically invaded others' land. This Article uses "trespass" in its broader sense.

5 See Malone, Ruminations on the Role of Fault in the History of the Common Law of Torts, 31 LA. L. Rev. 1, 14-15 (1970); Ogus, Vagaries in Liability for the Escape of Fire, 27 CAxiB. L.J. 104, 105 (1969); Winfield, The Myth of Absolute Liability, 42 LAw Q. REv. 37, 46-50 (1926).

The action on the case in common form for damage by fire appeared early in the fifteenth century. See text accompanying note 20 infra. It alleged that the fire had been the defendant's, and much was sometimes made of this proprietary element. See, e.g., Y.B. Pasch. 2 Hen. 4, f. 18, pl. 6 (1401). It was, of course, difficult, if not impossible, to ascribe a proprietary interest in a fire which arose from spontaneous combustion or the like. 
in 1390, a writ complained of the vi et armis burning of the plaintiff's house. ${ }^{6}$ The defendant answered that his house had caught fire "suddenly, by accident" and that a sudden gust of wind had caused the fire to spread to the plaintiff's neighboring residence. ${ }^{7}$ Pleas of this sort are numerous enough to make it certain that they were considered legally sufficient; otherwise, they would have drawn demurrers. ${ }^{8}$

It was also apparently settled that contributory negligence ${ }^{9}$ was a good defense to an action in trespass. Thus, defendants very often attempted to show that a plaintiff's injuries had been a result of his own foolishness. An interesting example of this defense occurred in 1376, when a plaintiff alleged an assault and battery, claiming that the defendant "had stamped on her with the hoofs of a horse." 10 The defendant said that she and the plaintiff had been watering their horses when the bridle of the defendant's horse fell off into the water; the horse, attracted by the whinnies of other horses, had then bolted. The plaintiff, the defendant said, had been trampled in an attempt to stop the runaway, and had received an injury which the defendant rather ungratefully characterized as the result of the plaintiff's "foolishness and fault." The defendant thus laid the injuries to the plaintiff's act and denied that there was any "malice or wrong" on her part."1

6 CP 40/516, m. 364v (1390), Case no. 35.7 in my forthcoming volume Cases of Trespass IN THE King's Courts 1307-1399 [hereinafter cited as Cases of Trespass].

7 The words of the plea are that the defendant "ignorante et invito ignis subito per infortunium in domibus [of the plaintiff] accendit et domos suas ibidem concremavit ita quod ex invino ventis flatu ignis ad domos ipsius [plaintiff] volavit et sic per infortuniam et contra voluntatem [of the defendant] dampna in hac parte ... evenit [to the plaintiff]." CP $40 / 516, \mathrm{~m} .364 \mathrm{v}$ (1390), Case no. 35.7 in CASES of TRESPASs, supra note 6 .

8 For examples of similar pleas, see 42 Liber Assisarum, f. $259 \mathrm{v}$, pl. 9 (1369); CP 40/417, m. 57v (1364), Case no. 35.4 in CASES OF Trespass, supra note 6.

9 See note 14 infra. See also note 16 infra.

$10 \mathrm{CP} 40 / 463$, m. 387 (1376), Case no. 2.18 in CASES of Trespass, supra note 6 . The words of the plea are: "eam cum pedibus cuiusdam equi conculcaverunt."

$11 \mathrm{Id}$. The words of the defendant's plea are that if any injury occurred, "hoc fuit ex stultitia et defectu eiusdem [plaintiff] . . . et non ex aliqua malicia sive injuria ipsius [defendant]."

In a similar case late in Richard II's reign, a defendant claimed that he had been shooting at the butts, and that after he had let an arrow fly, the plaintiff walked into the line of fire. Thus, the plea ended, the injury resulted from the "foolishness and fault" of the plaintiff and not from the defendant's "malice or will." $\mathrm{KB} 27 / 546, \mathrm{~m} .21 \mathrm{v}$ (1297), Case no. 2.31 in CASES of Trespass, supra note 6. The words of the plea are that the injury "fuit ex stultitia et defectu [of the plaintiff]." 
The causal relevance of a plaintiff's negligence is even more clearly demonstrated by a case from 1374. ${ }^{12}$ The defendant in this case claimed that while he was defending himself with a knife against an attacker, the plaintiff had stepped suddenly out of the shadows and that the defendant had accidentally stabbed the plaintiff, who had got in his way. So, the plea concluded, the injury had resulted from the plaintiff's "negligence, foolishness, and own act" and not from any "intention or malice" on the defendant's part. ${ }^{13}$ Contributory negligence was, therefore, well established as a defense to an action of trespass. ${ }^{14}$

Taken together, these two rules form an altogether unsurprising and unexceptionable proposition: that a person is not liable for injuries resulting from an act unless he "did" that act. ${ }^{15}$ In the case of "sudden happenings," the defendant has in an obvious sense not acted at all-these are acts of God-and in the case of the plaintiff's contributory negligence, it is the plaintiff, not the defendant, who is perceived as having "done" the act resulting in injury. But if a person was not liable if he had not caused the injury, was he necessarily liable if he had caused it? That is, was a plaintiff obligated to show not merely that a defendant had done the act complained of, but also that he had acted negligently? ${ }^{16}$ The note 6 .

$12 \mathrm{CP} 40 / 456, \mathrm{~m} .24 \mathrm{v}$ (1374), Case no. 2.21 in Cases of Trespass, supra

13 Id. The words of the plea are that the injury "fuit de negligencia, stulticia, et facto suo proprio ... et non voluntate sine aliqua malicia [of the defendant]."

A second case from 1374 also demonstrates the causal relevance of the plaintiff's negligence. The plaintiff in this case complained of being trampled vi et armis by a horse. The defendant replied that in a rescue attempt the plaintiff had foolishly got in the way. Therefore, the defendant's plea continued, the injury had been "the fault, and [had resulted] from the own act, of the plaintiff", and had not resulted "from [the defendant's] malice." CP 40/454, m. 33v (1374), Case no. 2.16 in CASES of TrESPASS, supra note 6 . The words of the plea are that the injury "fuit in defectum et de facto proprio [of the plaintiff]" and "non ex malicia [of the defendant]."

14 See also W. Holdsworth, 3 A History of Engutsh Law 378-79 (3d ed. 1923). Professor Holdsworth criticizes the use of the term "contributory negligence," but accepts the general rule that "if the act which caused the damage was the act of the plaintiff himself, then it is no cause of action." Id. 378 .

15 See Gregory, Trespass to Nuisance to Absolute Liability, 37 VA. L. REv. 359, 361-62 (1951); Malone, supra note 5, at 6; Wigmore, Responsibility for Tortious Acts: Its History, in 3 Select Essays in Anglo-Amerucan Legal History 474, 504-05 (1909).

16 Although some scholars maintain that medieval trespass law equated the absence of negligence with inevitability, see, e.g., W. Hor.DswORTH, supra note 14, at 381-82 (quoting Professor Wigmore); Malone, supra note 5, at $14 \mathrm{n.45}$, this Article will explore situations in which counsel and the courts seemed to use "negligence" to mean the failure to exercise reasonable care under the circumstances. 
fact that contributory negligence was a defense is of no help in answering this question, because that doctrine is as much at home in a legal system which imposes strict liability on defendants as it is in one which imposes only a duty of due care.

Negligence could certainly be a basis of liability and lawyers of the age very clearly saw the difference between acts of God and negligence, as a very interesting discussion about the ambiguity of the concept of "accident" reveals. Early in the century, a defendant sought to escape liability in Waste by claiming that the damage had resulted from accident (mischance). ${ }^{17}$ This promptly brought an objection from Serjeant Herle:

"Mischance" can be defined several ways: it can mean lightning, or thieves, or the defendant's fault [default]. And so it could be [i.e., in the last instance] that the defendant would be liable for an accident; and you have not said specifically what the mischance was. ${ }^{18}$

In other words, injuries which were accidental in the sense that they were unintentionally inflicted might still be compensable and the defendant's "fault" (that is, negligence) could be a basis for ordering the compensation. But aside from intentionally inflicted injury, was fault the only basis of liability? The view that the plaintiff was not in every case obligated to demonstrate fault on the defendant's part is supported mainly by two well-known aspects of the medieval law of torts. First, plaintiffs alleged the defendants' negligence only in very rare circumstances, and second, defendants even more rarely, if ever, tried to plead their own lack of negligence in bar to an action.

It will be the aim of this Article to explore the inferences which may be derived from these indisputable and undisputed facts concerning the part fault played in medieval tort-liability rules. I hope to show that references to defendants' negligence and intention in fourteenth-century cases can be explained by the fact that trespass actions were employed to subject defendants to both criminal and civil liability. I will demonstrate that proof of intention was essential to establish the criminality of the defendant's act, but that neither intention nor negligence was essential to establish a defendant's duty to compensate a plaintiff for injuries.

17 Reported in British Museum Additional Mss. 5925, f. 91b. Dr. Robert Palmer very kindly called my attention to this case.

$18 I d$. 


\section{Actions Founded on the Negligent}

Behavior of the Defendant

Actions in which the plaintiff's writ claimed that the defendant had acted in a negligent fashion are not numerous. We will leave to one side the cases in which negligence was alleged in the performance of some contractual obligation, the situation in which Assumpsit found its most common employment. Instead, we will examine the kind of case that involved what has come to be described as nonrelationship negligence.

There are only a handful of such cases in our period, all of them from Richard II's reign. A very interesting one from 1395 involved a writ alleging that a guest in the plaintiff's house had been several times warned to take care of his fire "lest any damage or harm befall the same house," but, heedless of the warnings, the defendant had "so negligently and indiscreetly guarded" the fire that the plaintiff's goods and houses had been burned up..$^{19}$ Unlike the action on the case in common form for damage by fire, which first appears a few years later ${ }^{20}$ and which uses the word "negligence," but seems to proceed on the assumption that liability would attach without fault, ${ }^{21}$ the instant case is clearly grounded in negligence.

A fire case early in the century, in which Walter of Langeton, Bishop of Coventry and Lichfield, was defendant, was taken to law through the special-commission device rather than common-law writ; its ticket into the King's court was not the general vi et armis jurisdiction. Because Langeton had abused his power as Treasurer of England, a special commission was appointed to try complaints against him "for his various and numerous oppressions." 22 One

19 CP 40/537, m. 260v (1395), Case no. 38.2 in CASEs of Trespass, supra note 6. The defendant entered a general denial. The words of the writ are that

cum... [the plaintiff] prefatis [defendants] ut ignem suum in domo predicta ne dampnum vel malum aliquod eidem domui eveniret salvo et secure custodirent sepius premunierit, predicti [defendants] premunicionem huiusmodi minime ponderantes, ignem suum in eadem domo tam negligenter et indiscrete costodierunt quod bona et catalla ipsitus [plaintiff] ad valenciam ... in domo predicta existencia ac domus illa pro defectu ipsorum [defendants] combusta fuerunt....

1d. A very similar writ was employed in 1371. See A. KraAfFy, ThE Action on THE CASE 214 (1951).

20 I have seen no examples of the common-form action in the fourteenth century. The first reported case is Y.B. Pasch. 2 Hen. 4, f. 18, pl. 6 (1401).

21 See Malone, supra note 5 , at 14.

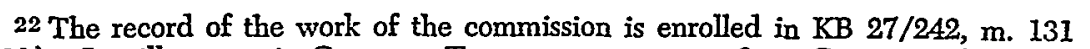
(1320). It will appear in CASES of Trespass, supra note 6, as Case no. 35.2. 
such complaint was brought by Jon de Shorne, who alleged that the Bishop and his men had, without invitation, lodged themselves in the plaintiff's granges and had burned them down along with their contents. ${ }^{23}$ Neither negligence nor vi et armis was alleged; the claim was that the damage had resulted from the defendants' outrageous conduct ( $p a r$ lour outrage). ${ }^{24}$ Probably the modern notion of gross negligence is close to the liability idea pressed here. In any event, the case was tried on the theory of negligence: The defendant answered that the loss had occurred "entirely by accident" and "not through the defendant's fault or lack of care"; ${ }^{25}$ the plaintiff replied that the fire had "occurred through the defendant's lack of care." ${ }^{26}$ The jury, in a special verdict, told a harrowing tale of recklessness on the defendant's part and concluded that the granges and their contents had been "totally burned up through the lack of care of the Bishop and his men." 27

Some years later, a writ complained that the defendant had so negligently and improvidently ridden his horse that the horse had knocked the plaintiff to the ground, causing him, in the stereotyped rhetoric of the case, to despair for his life. ${ }^{28}$ The defendant answered that he had hired the horse from someone he described as a "Hakenay Woman" and that immediately after he had mounted the animal had taken the bit in its teeth and run away with him. He added that he had had no previous knowledge of the animal's propensities and had unsuccessfully used all his strength to stop it. The horse, he conceded, had brushed against the plaintiff and knocked him down. The plaintiff first claimed that the plea was unresponsive, but three terms later he relented and replied that the defendant had in fact had notice of the horse's bad habits and

23 Id.

24 Id.

25 The words of the plea are that the fire "non fuit per defectum ipsius Episcopi aut per aliquan pravam custodiam suorum etc. . . . set incendum illud penitus provenit ex infortunio etc." Id.

26 The words of the reply are that "predicta combustio accidit ex defectu custodie ipsius Episcopi." Id.

27 The jury said that the granges were burned "pro defectu custodie ipsius Episcopi et hominum suorum ...." Id.

28 CP 40/543, m. 221 (1398) and CP 40/551, m. 119 (1398), Case nos. 38.1a and $38.1 \mathrm{~b}$ in CASES OF TRESPASS, supra note 6 . The words of the writ are that "cum idem [defendant] super quendam equm apud London nuper equitasset predictus [defendant] equm illum tam negligenter et improvide gubernaoit quod equs ille prefatum [plaintiff] ad terram ibidem dejecet ita quod de vita eius desparabatur ..." CP 40/543, m. 221 (1398), Case no. 38.1a in Cases of Trespass, supra note 6 . 
thus had been negligent. ${ }^{29}$ The jury found that the defendant had had no such notice, and judgment was given for him..$^{30}$

An important aspect of this case is that it indicates that the gravamen of the scienter actions (actions for knorvingly keeping dangerous animals) was negligence. The plaintiff very clearly has this theory in mind, for his amended reply states that the defendant, "before he mounted the aforesaid horse, had notice of the bad habits of the aforesaid horse, and thus the same [defendant] so negligently and improvidently drove the aforesaid horse that the horse threw the said [plaintiff] to the ground so that he despaired for his life." 31

Of course, what is most interesting about the fire and runningdown cases is not that they demonstrate that a person was liable for injuries attributable to his negligent acts. ${ }^{32}$ We have already seen that such was the case; ${ }^{33}$ indeed, it would be astounding if the rule were otherwise. What is most interesting about these cases is that the plaintiffs in them actually alleged negligence as the basis of liability. The question that immediately arises is why they should have done so if proving negligence was not necessary to their recovery. Although these cases provide no definite answers, one possible explanation is that these plaintiffs thought that by emphasizing the negligent aspect of the defendants' behavior, they could aggravate the wrong and increase their recovery. Damage verdicts are usually inscrutable and we can rarely discover what theories of liability, if any, lie behind them. Perhaps the plaintiffs alleged negligence simply to establish that defendants were the

29 See note 31 infra. note 6.

30 CP 40/453, m. 221 (1398), Case no. 38.1a in Cases of Trespass, supta

31 The words of the plaintiff's reply are that "idem [defendant] antequam ipse super equm illum ascendit habuit noticiam de malis condicionibus equi predicti. Et sic idem Johannes equm predictum tam negligenter et improvide gubernavit quod equs ille ipsum Nicholaum ad terram dejecit ita quod de vita eius desperabatur." CP 40/551 m. 119 (1398), Case no. 38.1b in Cases of Trespass, supra note 6.

It is possible, of course, to see the liability for damage done by animals as essentially strict, and to see the owner's knowledge as relevant to establishing him as the cause of the injury. If an owner has no knowledge of his animal's bad habits, it is easier to think of the animal as "doing" the injury, but if the owner does know, his act of keeping the animal makes it easier to think of him as producing the damage. Under this theory, in other words, the owner's knowledge is relevant because it takes the case out of the realm of accident in its broadest sense. Thus negligence is not an element to be provided by the plaintiff in addition to "cause"; it is the very thing which supplies a causal link otherwise difficult to make out.

32 I have noticed only one other case in the rolls involving a writ alleging negligent driving; the defendant did not enter a plea, and the case has already been noticed. See A. Kratry, The Action on the Case 102 (1951).

33 See the discussion of Serjeant Herle's remarks in the text accompanying note 10 supra. 
"cause" of the injury. But this much is clear: It is hard to draw believable inferences about liability rules from the fact that negligence actions were rare. It is well known that writs alleging intentionally inflicted injuries were employed to give remedies for unintentional torts; ${ }^{34}$ it is thus also possible that negligence was a part of a plaintiff's case even if he did not allege it.

\section{Actions in Which the Defendant Attempted to Plead in Bar a Lack of Fault}

If a defendant had ever pleaded a lack of negligence when a plaintiff had made no mention of negligence, that would be some evidence that fault was thought of as part of the plaintiff's case. Defendants apparently never did so, however. In a case from 1290,;5 defendants pleaded to a contra pacem $^{36}$ writ that the damage complained of, if any, had occurred by accident and not by any lack of care or wickedness on their part, ${ }^{37}$ but the plaintiff's count had in fact alleged "foolishness and a lack of care." 38 In Richard II's reign, a plaintiff brought a writ in common form, claiming that the defendant had burned his house vi et armis. ${ }^{39}$ The defendant replied that his master, the plaintiff, had ordered him to heat up an oven, and that when he did so, flames had shot out the back of it and consumed the plaintiff's house. The damage he therefore laid to the "incompetent and negligent manufacture and maintenance" of the oven. ${ }^{40}$ Issue was finally taken on the servant's "negligence and malice," ${ }^{41}$ but, whatever this phrase may mean, it first appears in the plaintiff's reply and not the defendant's answer. Thus, this case is no different analytically from those in which negligence is alleged as the basis for the action.

34 See Milsom, Trespass from Henry III to Edward III (pt. I), 74 LAw Q. REv. 195, 216-18 (1958), for a discussion of the enforcement of the scienter liability under color of a vi et armis writ.

35 Walter de Brainton v. Herbert of Pinn, 1 Select Cases in the Court of KING's Bencri 181 (G. Sayles ed. 1936).

$36 \mathrm{I}$ am assuming that the allegation of contra pacem was, for present purposes, in all important respects identical to the allegation of vi et armis.

37 Walter de Brainton v. Herbert of Pinn, 1 SELEct Cases in the Court of THE KnNG's BENGH 181 (G. Sayles ed. 1936). The words of the plea are that the damage, if any, "fuit per infortunum et non per aliquam malam custodiam seu nequiciam ipsorum." Id.

38 Id. The words of the plea are: "per eorum insipienciam et malum custodiam." note 6 .

39 CP 40/507, m. 366 (1387), Case no. 35.6 in Cases of Trespass, supra

$40 \mathrm{Id}$. The words of the plea are that the flames shot out "pro incompetenti et negligenti factura et reparacione eiusdem."

41 Id. The words of the reply are "necligencia et malicia." 
Research has uncovered only one case in which a defendant not charged with negligence offered a plea which might be taken to mean that he had not been negligent; but a close inspection reveals that this interpretation is almost certainly wrong and, moreover, that the defendant's intention had not been to avoid the duty to compensate. In 1379, what must surely have been a grudge case was brought by one neighbor against another. ${ }^{42}$ The claim, couched in typically formal terms, was to the effect that the defendant had broken the plaintiff's house and carried away parts of it. In fashioning his plea, however, the defendant revealed what was almost certainly the truth of the case. The parties to the action, the plea alleged, had owned adjoining townhouses in Rochester, and the defendant had hired masons and carpenters to remodel his. While they were engaged in this enterprise, the story ran, some stones and tiles had fallen on the plaintiff's house, causing a trivial amount of damage; indeed, the defendant said that the damage did not amount to a single penny. He also stated, and tried to plead, that the act had been without malice on his part and that the damage had been caused unintentionally and "against his will" ("encountre nostre gre"). The plaintiff objected that those facts did not amount to an answer to his writ, for they did not amount to a confession of liability, a denial of the facts, or a justification for "cause." 4 . No resolution of the plaintiff's objections is reported, but the court revealed little inclination to allow the plea.

At first blush, it is debatable what the defendant meant by his plea and what he thought proving it would accomplish. It is just possible that, by saying that the damage occurred "against his will," he meant to indicate that he had acted as carefully as anyone might be expected to act in the circumstances, that is, that he had in fact not acted negligently. If so, this case would be important as an example of an attempt by a defendant, in the context of a writ that did not allege negligence, to escape the duty to compensate by showing a lack of fault on his part. On balance, however, this explanation of the proffered plea seems unlikely, for it requires a somewhat contorted translation of the phrase "encountre nostre gre," and its aberrational, indeed unique, character would alone be reason for suspicion. If that is so, then all the defendant is saying is that he did not inflict the injury on purpose, and that is

42 Jankyn v. Anon. (1378), Year Books of RichaRd II: 2 Richard II 1378-79, 69 (M. Arnold ed. 1975).

43 As discussed below, the notion of "cause" was important in the fourteenthcentury law of torts. See text accompanying notes 55-56 infra. 
clearly irrelevant because the plaintiff certainly did not need to make out a case of intentional injury in order to recover. The defendant's motive in offering the plea, then, evidently lay elsewhere than in an attempt to escape the duty to compensate.

How is the defendant's state of mind relevant if it does not affect the plaintiff's right to damages? The answer lies in the fact that an order to pay compensation to the plaintiff was not the only incident of a judgment for a plaintiff in trespass. An unsuccessful defendant was also subject to amercement and to imprisonment and fine. Amercement was a small mulct, usually fairly trivial, which was exacted for any number of offenses that a person might commit during a trial. An unsuccessful defendant would be liable to pay it simply because his defense had been found false. As we shall see, ${ }^{44}$ however, imprisonment and fine were available against the defendant only if he was in some measure wicked and thus deserving of punishment. Moreover, the fine was often quite large, ${ }^{45}$ and a person from whom one was demanded would not be released from prison until it was paid.46

The defendant in this case argued specifically that even if he were liable for damages, he would not be liable for fine or amercement. His primary aim in pleading a lack of wrongful intention, therefore, was not to escape the duty to compensate, but to avoid imprisonment and its attendant fine. ${ }^{47}$ The court denied his proposition, but that was probably because he attempted to make his excuse too broad: He wanted to be exempt from both fine and amercement, and that was asking too much from his lack of mens rea.

\section{The Criminal Element in Trespass}

A number of scholars have noted that the action of trespass was in some sense criminal. ${ }^{48}$ As this section will demonstrate,

44 See section III infra.

45 As is well known, a fine was so called because it was paid to make an end (finis) of imprisonment.

46 Maitland made the same observation in F. MATTLAND, EQUTrY AND THE Forms of AGTION AT CoMmon LAW 343 (1910). Imprisonment was also used to encourage defendants to satisfy plaintiffs' damage awards, for imprisoned defendants were not released until they satisfied any judgment for compensation.

47 I believe that ordinarily the defendant's lack of intention was put in issue by the formulaic denial of "force and arms and whatever was against the peace," which preceded every plea in a trespass case. The plea may originally have been jurisdictional as well.

48 See, e.g., W. Holnsworth, 2 A Hrstory of English LAw 365-66 (4th ed. 1936); O. Holmes, The Common Law 34 (1881); 2 F. Pollock \& F. Martland, The History of ENGLish LAW 512, 526, 572-73 (2d ed. 1898); Milsom, Trespass 
it is now for the first time clear that the allegations of contra pacem regis and vi et armis were thought of in essentially criminal terms. Herle, J., said in 1321 that there could be no force (vi) without the intent to use force. ${ }^{49}$ It is clear from the context that he thought a jury finding of an unintentional battery would be repugnant to the plaintiff's claim of assault and battery; but, unfortunately, we cannot be certain what he thought the effect of such a finding should have been. Possibly the writ would have abated on the ground of repugnance of the verdict. Another possibility, however, is that the verdict would have been accepted as the basis of a judgment for compensation, although the defendant would not have been liable to imprisonment and fine because he had not acted with criminal intent. Indeed, this was a solution resorted to frequently in the fourteenth century. The matter is important enough to discuss in some detail.

In 1320, a defendant was alleged in a vi et armis writ to have submerged the plaintiff's goods in water after they had been consigned to him for carriage. ${ }^{50}$ The jury, in an interesting special verdict, indicated that, due to the inexperience and negligence of the crew, the ship had run aground and that the crew had taken some of the goods and sold them; the owner, it was said, had later ratified (acceptavit) the crew's acts. On these facts, the court gave judgment for the plaintiff for the value of the goods. The court noted in its judgment, however, that the defendant would be amerced only, and not imprisoned and fined, "because the said trespass was not committed against the peace." 51 The act was not against the peace apparently because possession originally had been obtained by the plaintiff's delivery and not by a trespassory taking.

from Henry III to Edward III, Part III: More Special Writs and Conclusions, 74 LAW Q. Rev. 561, 584-85 (1958). But see Malone, supra note 5, at 9-11; Woodbine, The Origins of the Action of Trespass (pt. 2), 34 YALE L.J. 343, 359-60 (1925).

Professors Woodbine and Malone assert that trespass originated in civil, not criminal, actions. Even if true, this assertion is not inconsistent with the notion that trespass actions in the fourteenth century combined elements of civil and criminal liability, for the origin of trespass is not crucial to this point. Moreover, there is reason to doubt this assertion. Woodbine, whom Malone follows, fails to mention that imprisonment and fine were possible consequences of a judgment for the plaintiff in trespass. He thus fails to explain how an action which supposedly derived from civil roots came to include criminal sanctions.

49 Houton v. Paston (1321), 2 EYre of London 282 (H. Cam ed. 1969). Herle's words are: "force ne put estre saunz volunte de fere force.".

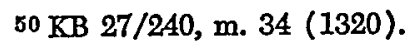

51 Id. The court's words are: "quia dicta transgressio non fuit facta contra pacem etc." 
In 1322, a writ for taking goods was brought against defendants who, according to the jury's special verdict, had purchased the goods from persons unknown who had stolen them. ${ }^{52}$ The court probed the jury with special interrogatories: Had the defendants been acting in concert with the thieves? Had they known that the goods belonged to the plaintiffs? The jury said that the defendants had in no way been connected with the original theft and had not known at the time they bought the goods that the plaintiff owned them, but the jury volunteered the information that the defendants had learned the truth immediately after the purchase. On these facts, the court gave judgment for the plaintiff, but no judgment was given for imprisonment. It is probably right to guess that the civil liability was clear from the beginning and that the purpose of the interrogatories was to discover whether the defendant was also, as we would say, guilty of a misdemeanor-receiving stolen goods.

A third example will suffice to make the association of contra pacem with criminal liability quite clear. The first common-law innkeeper's-liability case actually brought to a conclusion occurred in 1368.53 The plaintiff claimed that his goods had been stolen while he was lodged with the defendant; the defendant replied that he had given the plaintiff a secure room, that the inn itself was well built, and that the things had disappeared without his fault. To this plea the plaintiff demurred. The court sustained the demurrer, but in doing so refused the plaintiff's prayer for a capias-an order to arrest and imprison the defendant. He was liable to compensate the plaintiff, but, the court explained, because he was without fault, imprisonment and fine were not available. "It would not be reason," the Chief Justice noted, "for [the defendant] to be put in prison when there is no manner of fault [culpe] in him"; he was simply "charged by the law" with the duty to pay the value of the goods. ${ }^{54}$ In other words, the civil liability was strict, but the criminal liability was not.

Perhaps the most intriguing aspect of the criminal side of trespass was the impact of mistake on liability. This difficulty arose most often in the context of a distress when a lord accused of taking animals vi et armis would allege a "cause" of rent in

$52 \mathrm{~KB} \mathrm{27/249,} \mathrm{m.} \mathrm{5v} \mathrm{(1322).}$ (1368).

53 Y.B. Pasch. 42 Edw. 3, f. 11, pl. 13, 42 Lrber Assisarum, f. 260, pl. 17

54 Id. The words of the Chief Judge are: "il ne serra pas reason, quils serroient mis en prison, lou ils nad nul maner de culpe en eux, mes sont charge per le ley ...." 
arrears by way of defense. In the Eyre of London, an interesting colloquy between Herle, J., and the jury reveals that "cause" meant motive and that if the lord's motive for taking the beasts had been rent enforcement, he would not be liable to imprisonment and fine, even if, on the facts, he actually had had no reason to distrain for the rent..5 Herle explained that "one who thinks he has a right and makes a distraint for his rent ... does not act against the peace"; ${ }^{66}$ he distinguished between "cause" and "reason"-the first meant the subjective motive of the defendant, the second meant the objective reality of the situation. There was much discussion in the numerous cases of this kind about whether the whole writ should abate if the cause were found true, but no one ever contradicted the underlying assumption that imprisonment and fine were inappropriate in cases of this sort. Stanton, J., opined that if vi et armis lay in such a case, then so would an appeal of robbery, and that, he said, "could not be." ${ }^{57}$

The allusion to the appeal ${ }^{58}$ here is significant, for it is further evidence that the essence of the vi et armis and contra pacem allegations was wrongful intention, some element of mens rea. Clearly, this was the gravamen of the complaint in an appeal of mayhem, as some very interesting cases reveal. Sometimes mayhems were brought to law under a trespass writ for assault and battery and sometimes by an appeal. Technically, an appeal of mayhem was supposed to end in a criminal sanction only, but during the course of the fourteenth century the aim of this procedure became entirely compensatory. ${ }^{59}$ Eventually, a recovery in trespass became res judicata in the event of a later appeal arising from the same injury. ${ }^{60}$

The relationship between trespass and the appeal of mayhem was therefore an interesting one. Because the appeal of mayhem originated as a criminal procedure, it retained its allegation of felony. This meant that, even though the point of the "action" had become compensation, the question of intent was central to it

55 Medelane v. The Prioress of Stratford, 2 Exre of London 133 (H. Cam ed. 1969).

50 Id. 134. The words of Herle, J., are: "celui qe entende daver droit et fare destr(esce)... ne fet pas encontre la pees."

57 Id. 135. The words of Stanton, J., are: "sil en tiel cas feut receu al Quare vi et armis par meim la reson, il sereit receu a son appel de Roberie . . . quod esse non potest."

58 Appeal (appellum) was the distinctive procedure by which felonies were prosecuted. In appeals, plaintiffs always alleged defendants' felonious intent.

59 See generally Year Book 18 Edward III, lv-lix (L. Pike ed. 1857).

$60 \mathrm{~KB} \mathrm{27/312,} \mathrm{m.} 22$ (1338); KB 27/512, m. 6 (1389). 
and not simply ancillary, as in the case of an ordinary trespass action. We therefore get explicit pleas negating intention in bar to these actions, contrary to the situation which obtained in trespass. ${ }^{61}$ In one case, a defendant said that while he had been chopping a log with an axe at night, the plaintiff, his servant, had been holding a candle for light. According to the defendant, the plaintiff had held his hand too close to the point of impact, so that the defendant had severed one of the plaintiff's fingers and partially amputated two others. ${ }^{62}$ The defendant stated that the injury thus had occurred "per infortunium," and that it had been "contra voluntatem [suam]." ${ }^{83}$ The jury echoed these phrases in exonerating the defendant. It is likely that the Law French version of the latter phrase is encountre nostre gre, the expression employed by the defendant in the Rochester townhouse case discussed in section II. ${ }^{64}$

\section{The Impact of Pleading Rules and Some Conclusions on the Nature of Medieval LIability Rules}

The attempt to discover the mental elements necessary to give rise to liability in trespass turns out to be somewhat complicated. The first complication is that the action apparently had about it two distinct aspects, one having to do with the plaintiff's right to compensation and the other with the defendant's liability to punishment. The latter aspect, the criminal one, turns out to be fairly easily understood: Some wickedness of heart on the defendant's part was necessary to subject him to criminal liability. On the civil side of the action, the liability rules are slightly more difficult to divine.

For the reasons outlined in section $I,{ }^{65}$ it seems wrong to draw inferences about liability rules from the fact that actions affirmatively based on the defendant's negligence are rare in the extreme. However, the fact that defendants never attempted to take issue on their lack of fault is a relevant datum, even though reading appropriate conclusions from it concerning current notions of liability appears, at first, somewhat perilous.

The most telling difficulty is that the absence of pleas of this sort may simply be attributable not to any abstract liability rule but

61 See section II supra.

$62 \mathrm{~KB} \mathrm{27/422,} \mathrm{m.} \mathrm{40v} \mathrm{(1366).}$

$63 \mathrm{Id}$.

64 See notes 42-46 supra \& accompanying text.

65 See text accompanying notes 33-34 supra. 
rather to a pleading rule that barred the defendant from asserting such facts purely as a technical matter. To simplify somewhat, a defendant in a writ of trespass was obligated to choose between two kinds of answer: He either had to deny the physical acts he was alleged to have done, or he had to admit them and assign a cause for them. In the case of an assault and battery, for instance, an acceptable "cause" would have been self-defense. Now if a defendant wanted to say that he had hit the plaintiff accidentally (that is, nonnegligently), his story would not technically have fit either of the two modes of responding to complaints. He had, in fact, hit the plaintiff, so a denial was obviously of no use; moreover, he had had no cause, no justification, for hitting him because "cause," as we have seen, ${ }^{68}$ was thought of in motivational terms. Here, the defendant's case was that he had had no motive at all in hitting the plaintiff, for the act of hitting him had been unintentional. If his facts were usable at all, therefore, they were appropriately shown only at trial as evidence. If, however, a rule of materiality was enforced at trial, ${ }^{67}$ there is a question whether these facts were receivable as evidence. If they were, it is odd that no trace of an attempt to plead them is to be found in the Year Books in light of the fact that serjeants expended so much energy in attempting to plead evidence in so many other kinds of cases. The absence of such an effort seems, therefore, to argue for the immateriality of the facts and thus for a rule of strict liability. ${ }^{68}$

Moreover, it is likely that the rule that the plaintiff could not on the record vary from the original theory of his claim had an impact here. By the last quarter of the century, it is doubtful that a plaintiff who brought a common writ of trespass would have been allowed to take issue on the defendant's lack of negligence-even if it were pleadable-for that would have abated his writ. This principle is nicely illustrated by a case from the sixth year of Richard II, in which a person who brought a vi et armis writ complaining that his house had been burned down got maneuvered by

${ }^{66}$ See text accompanying notes 55-56 supra.

07 I have shown elsewhere that the rule of materiality existed in the fifteenth century. See Amold, Law and Fact in the Medieval Jury Trial: Out of Sight, Out of Mind, 18 AM. J. LEGAL Hist. 267, 275 (1974).

68 Professor Milsom has suggested that pleas of accident were nonexistent because the facts in them were appropriate to the general issue of "Not Guilty." This argument appears in its most developed form in S. Mrrsom, Historrcax Foundations of THE COMMON LAw 253 et seq. (1969). I agree entirely that the facts were not pleadable, but for somewhat different reasons, as stated. But if they were admissible as evidence, it does seem a little odd that no attempt to plead them was ever recorded. 
his opponent into saying that the burning had been unintentional. ${ }^{69}$ In his reply, the plaintiff said that the defendant had come to his house to distrain and had scared off his servants, whereupon the unattended fire had burned down his house. Both the opposing counsel and Belknap, C.J., opined that on these facts a writ of case should lie, one that did not allege that the burning had been intentional. They had in mind, of course, the view that vi et armis indicated an intentional wrong. "You should have taken a special writ on your case since it was not their intention to burn them [the plaintiff's house and his goods]," Belknap admonished. "Even though it [the injury] resulted from their act, it was nevertheless done unintentionally." 70 In a discussion very much like the famous eighteenth- and nineteenth-century ones in which an enormous muddle was produced in trying to sort out "unintentional" injuries from "indirect" ones, ${ }^{71}$ Belknap went on to give other examples of when Case and Trespass would lie. The plaintiff eventually changed his plea to one that conformed to his writ. For our purposes, however, the point is that at least in the latter part of the fourteenth century, plaintiffs who brought common writs would never have traversed a plea of lack of negligence because that would have abated their actions. Thus, it seems that plaintiffs were left with only one course of action-to demur. The question then again arises why defendants avoided pleading a lack of negligence: The most likely reason is that they were afraid they would lose. Again, a fairly strong case for the existence of a regime of strict liability in the Middle Ages is made out. ${ }^{72}$

Finally, the few judicial dicta concerning the nature of liability rules in the Middle Ages all seem to support the view that the rule of strict liability was a favored principle. For instance, in the Rochester townhouse case, ${ }^{73}$ Percy, J., fairly clearly indicated his

69 Professor S.E. Thorne, who is editing this Year Book for the Ames Foundation, very kindly made his proofs of this case available to me.

To Belknap's words are: "vous dussez aver pris vostre bref especial sur vostre cas depuis qil ne fut pas lour volunte de lez arder mez par infortune; mesqe il vint de lour fait uncor fut il fait contre lour volunte."

i1 See, e.g., Reynolds v. Clarke, 92 Eng. Rep. 410 (K.B. 1725); Scott v. Shepherd, 96 Eng. Rep. 525 (K.B. 1773); Leame v. Bray, 102 Eng. Rep. 724 (K.B. 1803).

i2 See text accompanying note 68 supra. It might be plausibly argued, however, that there is a much simpler explanation for the absence of attempts by defendants to plead that they had not acted negligently. To plead lack of negligence to a writ alleging an intentional injury is not merely unresponsive; such a plea is perfectly consistent with the plaintiff's case, for intentional torts are nonnegligent.

73 Jankyn v. Anon. (1378), Year Books of Rrchard II: 2 Rtchard II 1378-79, 69 (M. Arnold ed. 1975). See text accompanying notes $42-47$ supra. 
opinion that civil liability was strict when he asked the defendant's counsel whether the plaintiff had been offered any compensation "as between neighbors ... since this was done nonwilfully." it The reference to compensation due to neighbors for unintentional trespasses brings to mind the animal-escape cases in which the phrase inter vicinos (between neighbors) was very commonly employed. It is admitted by all that civil liability in such cases was strict. $^{75}$ Percy almost certainly believed, therefore, that compensation was due.

There are statements in a case from 1401 which seem at first to indicate some sympathy for defendants who unintentionally caused their neighbors injury, ${ }^{7 \theta}$ but a close examination of the case reveals that such a reading is erroneous. In the course of pleading a case for a client whose fire had got out of control and burned the plaintiff's house, a serjeant told the court that it seemed hard to hold the defendant responsible "when there is no fault in him." 77 But the serjeant was simply indicating that the fault had been in the plaintiff's servants, and that it seemed inappropriate to apply a strict liability standard to the master when there was, in fact, a negligent person who had caused the injury and who thus seemed more responsible. Moreover, the court replied: "What is that to us? It is better that [the defendant] be totally ruined than that the law be changed for him." is This clearly indicates a prevailing ethic in favor of compensation. This ethic was reaffirmed later in the fifteenth century when Mr. Justice Littleton opined that "when a man suffers damage, it is reason that he be compensated." 79 Thus, the inference to be drawn from all the

it Id. The judge's words are: "vous navez my allege pur le defendaunt qe vous ly tendistez ascunes amendez al hostel entre visnez a cause qe ceo fuist fait encountre vostre gree...." $1975)$.

i5 See Year Book of Richard II: 2 Richard II 1378-79, xx (M. Annold ed.

76 Y.B. Pasch. 2 Hen. 4, f. 18, pl. 6 (1401).

77 Id. The serjeant's words are: "ceo serra encounter tout reason de mitter culpe ou default en un home, lou il nad nul en luy, car negligence de ces servants ne poit estre dyt son fesauns."

$78 \mathrm{Id}$. The court's words, per Thirning, J., are: "Que est ceo a nous? Il est mieitux que il soit tout defait, que la ley soit chaunge pur luy."

79 Y.B. Trin. 6 Edw. 4, f. 7, pl. 18 (1467). Littleton's words are: "si un home ad damage il est reason que il soit recompence." Other contemporary judicial pronouncements are to the effect that liability is strict. See, e.g., the remarks of Rede, C.J., in Y.B. Trin. 21 Hen. 7, f. 27, pl. 5 (1506), in which he discusses the concept of the unintentional trespasser. It is significant that the concept of pure negligence is simply absent from any medieval discussion.

Professor Milsom has argued that because facts of accident were appropriate simply as evidence under the general issue and because jury control techniques 
available evidence is that in fourteenth-century trespass actions civil liability was strict. It would be for a later age to invent the proposition that some showing of fault was ordinarily necessary in order to impose on an actor the duty to compensate.

were rarely employed the law of torts remained undeveloped in the middle ages. See S. Musom, supra note 68 , at 10 . No doubt the law of torts was somewhat amateurish by modern standards, and Milsom's insight that this was caused by the rudimentary nature of medieval trial techniques is a most significant contribution to our understanding of medieval law. Still, all that is required to have an elementary liability rule is for jurymen to have shared a common assumption that liability was strict. Since all the (meager) evidence is that this is what judges thought, the likelihood is strong that they were expressing a community norm, which jurors applied in the cases entrusted to them. 